\title{
The Urgency of Children Education in Preventing Mass Ignorance in Indonesia
}

\author{
Firman Mansir \\ Universitas Muhammadiyah Yogyakarta \\ Corresponding Author. Email: firmanmansir@umy.ac.id
}

\begin{abstract}
This study aims to explain the importance of children's education in preventing ignorance. This study used a qualitative approach. As for the subjects of this research are Indonesian children who are in Muhammadiyah Yogyakarta School. This research was conducted online considering the Covid-19 pandemic is still engulfing Indonesia, so face-to-face via zoom and direct interviews were conducted. The data analysis technique used was descriptive qualitative. The results show that early childhood education is very important to prevent stupidity because children need to be given insight and understanding about the world of children. So that they are able to face their lives appropriately and are not affected by the currents of social life. Thus, this study showed that educational failures could result in ignorance for Indonesian children. The emergence of mass ignorance, of course, did not happen suddenly, but there was a cause to it. Experts stated that the mass ignorance is due to the lack of education, the lack of knowledge about science and technology and the laziness of some children. Therefore, the mass ignorance in children's education should be erased by giving necessary education to advance their thinking. Also, children's education must be positioned as the target of all educational endeavors because education aims to inculcate all aspects and values of a good life to prevent and reduce mass ignorance in Indonesia.
\end{abstract}

\section{Article History}

Received: 20-09-2021

Revised: $29-10-2021$

Accepted: 08-11-2021

Published: 11-12-2021

Key Words:

Children Education,

School, Ignorance.

How to Cite: Mansir, F. (2021). The Urgency of Children Education in Preventing Mass Ignorance in Indonesia. Jurnal Kependidikan: Jurnal Hasil Penelitian dan Kajian Kepustakaan di Bidang Pendidikan, Pengajaran dan Pembelajaran, 7(4), 810-821. doi:https://doi.org/10.33394/jk.v7i4.4306

https://doi.org/10.33394/jk.v7i4.4306

This is an open-access article under the CC-BY-SA License.

\section{Introduction}

Experts revealed that children are a gift and deposit from God Almighty that needs to be protected so that they need to be educated to grow into human beings who are useful for the environment, nation and state (Fakhruddin, 2014). However, some experts argue that every child has their own talents and interests according to their rights and abilities, especially in terms of education (Tanu, 2019). Because every child has had his own potential since he was born, it does not escape the supervision and care of the tea people because this is the duty of parents (Sukri, 2015). The condition is to accept the condition of the child as a whole. From that child, the need for educational knowledge that is able to provide services to children according to their abilities, interests and talents. In education, such as the characteristics of children's creativity and development according to their age, the needs of facilities and infrastructure must be fulfilled and adapted to the circumstances of each child intellectually, emotionally, and socially.

The early age is the golden age for the development of children in the learning process (Iqbal \& Islam, n.d.). This period is an important period for the growth of children because they can recognize various kinds of things in their environment that can shape character and mental abilities to improve both cognitive abilities and social abilities. Therefore, education for early childhood can be in the form of stimulation introduced by 
parents, teachers, and the surrounding environment. This introduction is needed in early childhood to optimize the talent and growth of the child to grow and develop accordingly.

Education is important for human life, so all people are required to seek knowledge by studying in educational institutions such as schools (Ali, 2009). In accordance with that, there are levels of education for every age, ranging from elementary, junior high, high school to college. This is in line with the 1945 Constitution, especially in the fourth paragraph, to educate the nation's life and participate in carrying out world order (UUD, Republic of Indonesia). Even the very first verse of the Qur'an that was revealed is about a call to read and study. Allah SWT reveals: "Recite in the name of your Lord who created." (Q.S alAlaq:1)

From the verse above, it is shown that education is very important. However, the quality of education in Indonesia is not as good as in other developed countries since many Indonesians cannot read, write and count and their human resources are not qualified, so they cannot compete competitively. This is evidenced by the results of research from the United Nations Development Program, which shows that Indonesia is ranked $110^{\text {th }}$ out of 188 countries in terms of education. Based on these facts, it shows the minimum level of education in Indonesia (Yuliani, 2016). Thus, what can be done to improve the situation is to save the next generation of the nation from ignorance due to their actions.

Education is an attempt to change people for the better, and the essence of this change is a change in values (Mansir, 2017). Thus, the purpose of educational efforts is to teach values. This statement is the same as what was expressed by Mulyana that values are the efforts of all education. Values which are a core in achieving the form of national education are also reflected when those contained in Law No. 20 of 2003 concerning the National Education System (UU Sisdiknas) Article 3 where it is stated that national education aims to grow the potential possessed by students so that they become people who believe and fear God Almighty, have a noble character, are healthy, knowledgeable, capable, creative, independent, and make him a citizen of the Indonesian nation who has a democratic and responsible spirit. The purpose of national education is to know that part of the goal of national education is value. Thus, it can be concluded that the core of the form of national education is a value. Therefore, all efforts are made to achieve the goal of national education is to achieve this value.

Instilling values is a goal of national education that cannot be obtained instantly but requires a sequential learning effort and must be planned as best as possible (Marliani, 2019). One of the efforts made by superiors or government officials who have high positions, namely to realize this is by providing educational services intended for all citizens through all educational institutions and units as organizers of learning activities with paths, levels and types of learning as regulated in Laws. From all the descriptions above, we can see the importance of the existence of schools as institutions that provide educational services and places to learn for students. Therefore, the role of the principal can influence to realize of ideas, hopes, and also goals to be achieved in national education. So that schools should be used as centers of learning, empowerment and the development of values from all aspects of life.

The phenomenon shows that the number of children who do not go to school in Yogyakarta is still high and this can be found in. Many children who work the during of school hours, in order to help their parents. The fact that happened in the field, the children who work in helping the family economy are those who do not go to school. Meaning they do not get an education. Therefore, in this context, the authors are interested in knowing the importance of children's education so that in the future, a similar phenomenon will not occur 
again in Indonesia. This research was conducted at the Muhammadiyah school in Yogyakarta. In this context, the research subjects are children who are in Muhammadiyah schools in Yogyakarta.

In this case, the school is used as an institution to organize education, and the learning process must have a complex and dynamic system. Schools are not just a meeting place between students and teachers but also places for the transfer of knowledge as well as the formation of the character of each child so that every child who becomes a student in the school environment is able to grow into a better person according to the rules of social life. Therefore, schools must be able to produce human resources and have good quality with good character. Therefore, the purpose of the article review is to find out the results of previous research related to children's education, so that this research is able to see and distinguish various existing research results.

\section{Research Method}

The method of this research is to use a qualitative method. As for the research subjects, namely the children of Muhammadiyah schools in Yogyakarta. Meanwhile, the research instruments used the observation, interviews and documentation. This study applied a qualitative approach. Therefore, in conducting data analysis, literature analysis was carried out on various data that had been prepared. Meanwhile, in the process of analyzing the literature, a descriptive analysis was used in order to produce accurate data according to the methodology and answer the problems in this study. Accordingly, the resulting data was valid because the method was in accordance with the research topic.

\section{Results and Discussion}

Judging from psychology, the development of children aged six to eight years is still in a phase that spans from zero to eight years of age (Alexander, 2010). Therefore, learning taught to families or in non-formal educational institutions should be more towards an ageappropriate educational atmosphere by prioritizing design in the world of learning by playing. Growth and progress at an early age is a sign of psychological transformation, according to Kartini Kartoto, which is supported by environmental factors and the child's learning process at a certain level. The theory of growth put forward by Freud says that personalities grow through a series of stages in childhood in which they seek pleasure from psychosexual energy or libido (the desire behind the perpetrator) in certain sensitive areas.

According to Freud, the age of zero to five plays an important role in the development of a child's personality (Mansir, 2018). If this stage is passed perfectly, then the child will have a healthy personality. On the contrary, if this stage results in failure or problems, the child will be stuck on it even though he continues to grow, and may cause fixation. The main factor that makes this stage fail is that the kid is too dependent on others. In this developmental phase, five phases must be passed, including the oral stage at the age of zero to one year, the anal stage at one to three years, the phallic stage at three to five years, and the latency stage at age five to puberty and the genital (post-pubertal) stage.

1) Oral Stage (zero to one year old)

At the oral stage, the baby begins a search that can make him feel satisfied to meet the oral needs, among others, by sucking, drinking, or eating. The mouth is the organ that plays the most important role in this stimulation stage and is also the one most often used in infant activities to fulfill the baby's self-satisfaction. The satisfaction that babies get at this stage is in the form of sucking their mother's breast or even sucking their own thumb. Meanwhile, the dissatisfaction received by the baby in the form of vomiting food, which the baby felt, was 
not in accordance with the satisfaction value. On the other hand, the mother's role is very crucial at this oral stage because this stage will determine the baby in the future through the satisfaction that the mother gives to her baby. If the mother fails to provide adequate satisfaction to the baby, in the future, the baby in adulthood will have a dependent nature, bite nails, or even smoke.

2) Anal Stage (one to three years old)

The anal or anus has a special role at this stage. Babies who are under 3 years old just find out how to get rid of the feces in their stomachs or the leftovers of the food they eat every day. This is where the role of the rectum is very influential at the anal stage as a tool to remove feces in the toddler's stomach. At this stage, the role of the mother is also needed to train toddlers to do potty training. The mother should train the child to start defecating independently so that the child can do it properly and correctly, such as entering the bathroom with the right foot first, and going out with the left foot or using the left hand to wipe.

3) Phallic Stage (three to five years old)

The phallic stage lasts approximately 2 years. At this stage, the stimulant is no longer in the mouth or rectum, but the stimulant is on the genitals instead. In this phase, children begin to have an interest in the differences between boys and girls. Boys aged 3-5 years generally tend to be closer to a mother; perhaps so are girls. The role of parents in this phase is also vital to guide their children because, at this phase, toddlers still have a high selfish nature and are still less sensitive to the surrounding environment.

4) Latent Stage (five to twelve years old)

This stage does not fully use stimulants like the previous 3 stages, even though the child is still experiencing rapid physical and spiritual development because, at this stage, sexual stuff is blocked. At this age, children tend to develop their abilities further, for example, doing homework, playing with friends, and starting to pay attention to making friends but not paying more attention to the opposite sex. And at the age of 5 to 12 years old, children are looking for the ideal figure among adults of the same sex. For example, boys usually idolize a father.

5) Genital Stage (twelve years old or older)

Age 12 and older can be classified as an adolescent. At this age, the reproductive organs have matured, and satisfaction is in the vital organs. In this genital phase, the affection for the family has decreased or even does not exist because the affection possessed by the child has been transferred to the opposite sex and is no longer for his family anymore. The sexual instincts of the child become active and can become aggressive because, at this period, the child's reproductive organs have matured. It is characterized by a diversion of attention towards seeking satisfaction or seeking pleasure.

\section{The Role of the Family for Child Development}

The family is the starting place to learn and to receive guidance. From the beginning, the child will be taught by his family and introduced to his Creator, Allah SWT. Likewise, learning and knowledge of morals and character (Veronika \& Andriani, 2021), can be obtained through the daily habits of their parents at home, such as teaching children how to speak well and politely towards elders and respect others. Children should also be given good teaching about how to choose good things regarding the needs of life (Mansir, 2020). Thus, children will shape the basic abilities that will determine the quality of their life. Therefore, family is the most important factor in shaping the future of children. In terms of development and growth, the family has instilled it from an early age. Actually, children in the mother's womb can already feel all the activities carried out by their parents. 
In this case, it is not surprising that children are raised and grow in unfavorable conditions because they are very influential in the womb. Therefore, the family must know a lot about what developments the child can do at home. When the child is still in the womb, parents play an important role. Therefore words, actions, and actions must be educative. When the child is born, parents must know how to give affection in the form of loving and caring for the child according to what they need. Then, when the child reaches the age of two, this is a stage that is considered quite potential where the child has the ability to imagine himself, which can grow his creativity and be very productive in his future. However, during certain phases, it turns out that many parents are not able to provide flexibility for their children to be able to express according to their imagination leading to many behavior deviations.

The restraint of children by parents proves that it is not a good thing for the intelligence and creativity of every child. It can even result in not being good for the psyche. Some parents cook their children to obey the wishes of their parents, which can hamper the creativity of the children themselves (Suntana, 2015). Parents must change this behavior in the introduction process to educate and teach science to children of this age (Mansir, 2020). There is an interesting saying from the Lebanese poet Kahlil Gibran, who says that our child is not us, nor is anyone else. He is himself. And his life in an era that is not the same as his master's. Therefore, children need something different from what we need. As parents, we can not give him a stand but a form of affection, and in fact, they are not yours but with you. The phrase is very appropriate to represent who the child really is and how it should be done for their best growth in the future. Therefore, the above expression should be used to see the child's position towards the family. Especially parents, who want a lot to make their children into individuals who are creative, dynamic, and productive. So far, families are still inclined to things done in the past and applied to their children in childhood which should be changed in terms of educational and dynamic patterns.

In fact, children have their own world, which is not the same as parents as adults. With the freedom to do anything, it is not an act of prohibition for children but also with the activity of children to be more productive (Baharun, 2016). But the world that a child has can evacuate a series of talents that exist within a child, and it is necessary to realize that children are individuals who grow and develop (Mansir, 2021). Therefore, the role of parents in educating their children is very large, and they are also required to be able to provide an understanding of the conditions and patterns of child growth and development so that parents can guide their children according to their growth and development period. Then parents also have an obligation to have the ability to create a pleasant and conducive family atmosphere in order to help all their children grow and develop. Therefore, a prosperous family with perfectly directed children will be achieved. The most important goal of the family is to be a place where children grow and develop optimally, and child development makes children a more mature person and has a great sense of responsibility.

According to the concept of childhood education, what occurs in Early Childhood Education (PAUD) should be able to be conditioned in an active, creative, and full of fun and fun learning situation because of the learning while playing method (Taubah, 2015). Thus the need for security and comfort must still be met. For elementary school students, at the beginning of school, they are taught about the concept of calculation, for example: choosing learning media by singing or in other ways that are easier to express (Mansir, 2021). Using the same learning method as fun, the purpose of education for pre-school-aged children is different from the goals of education for early-primary-aged children. If education intended for preschool children aims to optimize growth and development in child development, it is 
known that the methods in early elementary school children's education aim on helping each child to be able to follow the stages in educational institutions according to the level that has been set.

In addition to its purpose, which is to help develop various abilities, talents, interests and knowledge of children to maximize their intelligence. Learning methods for children must be adapted to the design of education for children at an early age (Adler, 2015). Provide instruction in reading and counting plans. For example: by using a way that is interesting for children and can be enjoyed by children. And the most important thing is to make children the center of learning and dominate in the classroom. During its implementation, this is commonly called CBSA (Active Student Learning Ways) instead of CBSA, which means "Record the Book Until the End". During early childhood learning, it is given to the family and must rely on the PAUD plan (Johni Dimyati, 2013). In fact, a series of education created by parents provides sufficient breadth for children to increase various creativity and independence (Mansir, 2020). Also, the greater section of the time must be spent with their families and not at school.

\section{Education Problems in Indonesia}

National education is the implementation of the 1945 Constitution (UUD), especially in Article 31. Article 31, Paragraph 1 explains the right of every country to obtain every education, and paragraph 2 explains the obligations that each country has to organize an education system. In the current era, the national education system is legally covered by Law (UU) Number 20 of 2003 concerning the National Education System (Sisdiknas). In its implementation, education is developed based on philosophical, sociological, and juridical foundations. Philosophically, Pancasila is the most important foundation with its own roots from two insights: the view of the Indonesian people and the insight into education. Apart from that, other aspects that are no less important are economics, politics and law. This view is what makes education a concern for all parties.

Sociologically, education is a cultural and social habit that is important to create a democratic life (Lu, 2012). At this time, the nation's collective awareness will emerge in order to solve problems and provide various solutions to social problems faced by Indonesia that need to be further developed (Mansir, 2020). Therefore, education is planned to reduce socio-economic disparities that occur in society. And the solution to deal with this problem is to make improvements to all problems that arise in social life, for example, social disintegration, inter-ethnic conflict, violence, as well as mass stupidity in Indonesia. Juridically, the education system in Indonesia also has legitimacy and is subject to the laws that apply in our country's system. The 1945 Constitution is a juridical basis that is owned by the Indonesian nation, which our foundation shows that education has an important role in ensuring that every society is able to have the development and continuity of their life because, after all, it affects how the conditions owned by the Indonesian people have an increase in the order of life nationally and comprehensively.

Education is an important thing and has been mandated in the preamble of the 1945 Constitution as the juridical basis of the Indonesian nation, namely to educate the nation's life which is considered to have a more comprehensive meaning because it concerns the entire community in Indonesia when compared to only teaching (Mansir, 2019). The mission carried out by the implementation of education in Indonesia is to realize the education system as a culture and habit in a strong social environment in order to provide assistance to all Indonesian citizens to be more cultured so that they are able to grow into a society that has high quality that has the ability to respond to everchanging challenges. The main issues in the 
implementation of education in Indonesia are broadly related to globalization, implementation of compulsory education, national education standards, decentralization of education, and school curricula.

1) Globalization Impact

Globalization cannot be avoided. Facing globalization depends on how one can take meaning in learning. For example, if one can understand the meaning of globalization well with a good view, such as globalization, it implies the need for quality learning and adaption to international standards. Therefore all policies that will be taken in the field of education are aimed at achieving all these goals (Mansir, 2020). However, if globalization is interpreted as lacking, for example, globalization can lead to the vulnerability of influences from foreign cultures because it is contrary to the norms and rules of social life.

2) Obligatory Learning

Law No. 20 of 2003 acts as a benchmark due to amendments made to Law No. 2 of 1989, which discusses the national education system. It stipulates that education must be implemented for all citizens for a minimum of 9 years, consisting of six years at the elementary school and three years at the junior high school level after adjusted to the Law of 1994. In carrying out compulsory education for 9 years, the National Education Office aims to improve the quality of human resources. In implementing the government's program, there are some obstacles:

a) Lack of understanding of the ability of the community about the importance of education, especially for a child.

b) There are still too many or high numbers for each student who drop out at the SD or MI and SMP or MTS levels, while the continuation rate to SMP or MTs is still not maximized.

c) The participation rate is not optimal, both the gross enrollment rate and the pure participation rate at the junior high school and Madrasah Tsanawiyah levels.

The level of public awareness of the importance of education can be divided into 4 categories: People who have better financial capabilities and also awareness of the importance of education, People who have adequate financial capabilities but low awareness of the importance of education, People who have financial capabilities with a low level of awareness of the importance of education, people with the low financial ability and have a low level of awareness.

3) National Education Standards

It is the smallest standard that is owned if it is related to various interrelated aspects in implementing the national learning system and must be implemented by organizers or educational institutions spread throughout the Republic of Indonesia. This standard is also used as a basis or basis for monitoring, planning, and realizing education in the context of realizing quality national education. This education also has the aim of forming character and character and building civilization so that it can become a nation that has dignity and guarantees the quality of national education to educate the life of the nation and state (Sari \& Bermuli, 2021). This standard is also continuously refined, well planned, and has a direction in accordance with the demands of changing cultural behavior in people's lives.

Government Regulation No. 19 of 2005, which discusses matters relating to the National Education Standards and the Law on the National Education System, has called for a signal to be given to every educational institution so that each of these educational institutions in the form of schools is able to carry out School-Based Education Management which is often known as MBS who has been advised by the regulations that have been made. The implementation of SBM has an obligation to refer to the fulfillment of 8 national 
education standards (SNP) that have been set. These standards include content standards, process standards, graduate competency standards, educators and education staff standards, facilities and infrastructure standards, management standards, financing standards, and educational assessment standards.

4) Decentralizing Education

Decentralization in the education sector resulted from the enactment of legislation No. 22 of 1999 that had an impact on the implementation of education in each autonomous region. The structure of Law No. 22 of 1999, especially in Articles 1 and 2, states that the central and regional governments are autonomous. If the autonomous region has its own area consisting of provinces, districts, and cities, it has been given the authority to stand alone and does not have a hierarchical relationship between one autonomous region and another so that it is said to be a unified whole in the autonomous regional government because it does not have a hierarchical relationship, causing them to have a coordinating relationship and cooperative partnership. The administration of government in each of these autonomous regions remains part of the framework of the unitary state of the Republic of Indonesia. According to Article 11, which has been stated in Law No. 22 of 1999, education is also included in one of the many areas of authority that have been given to districts/cities. According to articles 3 and 4 in Regulation No. 25 of 2000, in addition to organizing special schools and structuring teachers (Mansir, 2020), the implementation of basic and secondary education is entirely the responsibility of the district or city. The government's task, according to Article 2 Paragraph 1 and Paragraph 3 point 13 in Regulation No. 25 of 2000, there is more to the preparation of national planning and its control, the establishment of various standards and requirements as well as the establishment of an educational calendar and the number of effective study hours per year. Apart from this provision, the whole area becomes the authority of the district or city.

To realize the decentralization of education, we are also faced with several problems, including the ability to finance education, the existence of quality gaps, efficient management and equal distribution of opportunities to obtain the education (Mansir, 2020), as well as involving the community in learning, the diversity of regional capabilities in education financing is the main issue related to implementation.

5) School's Curriculum

Conceptually, curriculum development can actually use a centralized or decentralized approach. The second is with their respective approaches to children who have advantages and disadvantages (Devine et al., 2010). Among them are the advantages of centricity that make it easier for consensus to be reached. This is very good for maintaining national culture and helping to expand learning and easy to innovate. As for using a decentralized approach, this has advantages in terms of adjustment in terms of integrity and local social and cultural conditions but has drawbacks. Even more so, the drawback is achieving consensus in the diversity of regional needs. Due to the existence of national education standards, especially for content standards and graduation competencies, the curriculum also needs to be developed again for the level of education. Associated with the needs of the nation's development which became the formulators, especially those who formulated the opening of the 1945 Constitution, at that time had an understanding that the life of the Indonesian people in many ways was not yet intelligent. The image of an intelligent nation in their view is the developed European nations and the nations living in other developed countries. When associated with the vision of national development, the intelligent nation is a nation that is independent, highly competitive, prosperous, just and prosperous. The Indonesian nation and other colonized nations are seen as a nation that is not yet intelligent, and their lives are still 
colonized, so they do not have independence, let alone competitiveness, and the level of welfare, justice and prosperity is also still low. In order for the Indonesian nation to become a developed nation, it must become a smart nation. To become an intelligent nation, the efforts made are through education. That is why, in article 31, especially in paragraph 1, every citizen has the right to receive teaching or education, then continued in paragraph 2 that the government has an obligation to organize a system in national education (Sewell \& Newman, 2014).

\section{Education as Main Solution for Indonesian Children}

Many problems in the education of Indonesia, such as mass ignorance, poverty, high levels of laziness, and others, must be addressed. In order to prevent, reduce, or even overcome the existing problems, it is necessary to improve the quality and relevance of education through the following strategies:

1) Improving the Services of Education Personnel and Educators

Educators have an obligation which is required to do what has become their duty correctly, namely not only transmitting knowledge but must educating and guiding their students in order to achieve the goals of national education. Likewise, educational staff must serve each student well, politely, friendly, and with character (Ariani et al., 2021). So that students feel comfortable in studying. The quality of teachers greatly affects the quality of education because the teacher is a place for students to learn, giving us knowledge that has never been obtained before and asking about what we do not know. Being a teacher is not easy, not people who rely on intelligence alone, but people who can accompany intelligence and also a good personality and a sincere spirit, given from the deepest heart. Therefore, teachers are the chosen people that all humans cannot do it easily. And the teacher is the root of the civilization of a nation, if the roots are strong, then the whole is strong, and vice versa if the roots are weak, then the tree will not last long.

2) Optimizing Decentralized System

The decentralization system in Indonesia has been implemented. This is reinforced by Law number 23 of 2014. However, it is not well optimized, so education is more focused on urban areas than rural areas.

3) Improving the Facilities and Infrastructures in Schools

Facilities and infrastructure are very important for a school (Mansir, 2021). The necessary facilities such as rooms, libraries, laboratories and much more, while the infrastructure consists of buildings or places that can be used properly, such as school buildings, sports fields, and much more. Therefore, there must be equalization of facilities and infrastructure in all schools in Indonesia.

4) Developing Relevant Curriculum

To realize a relevant education, it is necessary to develop a curriculum that is in accordance with the market and also the job (Mansir, 2021). Investments are needed in the development of primary and secondary education units, non-formal education as well as tertiary institutions.

5) The Government's Contribution and Assertiveness

The government must be strict about enforcing rules that have been set and about assessing them sustainably. For example, the 1945 Constitution Article 31 Paragraphs 1 and 2 states that every citizen has the right to receive teaching and the government seeks and organizes a national education system, but if you look at the sound of the 1945 Constitution article 31 paragraphs 1 and 2, it seems that it has not been implemented smoothly, the evidence is that there are still many small children who are still selling on the side of the 
road, some are scavengers or even beggars. This is a small picture of what is happening in Indonesia. Therefore it is appropriate for the government to re-control and clarify the laws.

When we compare ours to America, they do an amendable compulsory education program and also get the full attention from the government. In America, if a child is wandering the streets during school hours, the government will find out who the parents of the wandering child are and then ask the parents why their child is hanging around outside school during school hours. If the parents cannot provide a clear reason, they can even be imprisoned. That is an evident illustration of the firmness of the regulations that should be taken as an example and be applied in Indonesia. Hopefully, in the future, education in Indonesia will be evenly distributed and no more children who drop out of school due to costs or other factors (Yus, 2011). The government should have participated in dealing with education problems in Indonesia, especially in cases of mass ignorance.

\section{Conclusion}

Children's education in Indonesia is very important and has a role to fortify themselves from various social currents of life, including ignorance. Indonesian children need to get a proper education so that they are able to have the foundation and provisions to live the next life that is more winding and tough. With education for children, in the future there will be no more discoveries about child exploitation, no more children working on the roadside just to help their family's economy. However, our hope is that the children can go to school and get a proper education. Therefore, the role of the government, teachers and parents or the community is needed, so that they can jointly protect and protect Indonesian children from ignorance. Consequently, the problems of education in Indonesia are the influence of globalization, the implementation of nine-year compulsory education, national education standards, decentralization of education, and school curricula. In order to prevent or reduce, or even overcome existing problems, it is necessary to improve the quality and relevance of education through the following strategies: improving services of teachers as educators, optimizing decentralization, improving facilities in schools, developing relevant curricula, and government's contribution and assertiveness in realizing the ideals of a better Indonesian education.

\section{Recommendation}

In order to improve and develop the insight capabilities of Indonesian children, in the future, a direct role from the government is needed, in this case Mininstry of Education and Culture RI. The problem of ignorance is no longer a big problem for Indonesian children. Therefore, direct assistance for Indonesian children is needed. In addition, so that this research can produce wider data, it is necessary to continue with comparative research between countries.

\section{References}

Adler, A. (2015). The education of children. Routledge.

Alexander, R. (2010). Children, their world, their education. Final Report and Recommendations of the Cambridge Primary Review, 316.

Ali, M. (2009). Pendidikan untuk pembangunan nasional: menuju bangsa Indonesia yang mandiri dan berdaya saing tinggi. Grasindo.

Ariani, W., Mindrati, E., Winarni, R., \& Surya, A. (2021). Analisis Nilai Karakter Motif Flora Batik Ngawi Sebagai Muatan Pendidikan Seni Rupa. Jurnal Kependidikan: Jurnal Hasil Penelitian dan Kajian Kepustakaan di Bidang Pendidikan, Pengajaran dan Pembelajaran, 7(1), 122-130. doi:https://doi.org/10.33394/jk.v7i1.3141 
Baharun, H. (2016). Pendidikan Anak Dalam Keluarga; Telaah Epistemologis. PEDAGOGIK: Jurnal Pendidikan, 3(2).

Devine, D., David, M. E., \& Menter, I. (2010). Children, their world, their education: Final report and recommendations of the Cambridge Primary Review. British Journal of Sociology of Education, 31(6), 813-826.

Fakhruddin, A. (2014). Urgensi pendidikan nilai untuk memecahkan problematika nilai dalam konteks pendidikan persekolahan. Jurnal Pendidikan Agama Islam-Ta'lim, 12(1), 79.

Iqbal, M., \& Islam, J. P. A. (n.d.). PENINGKATAN KUALITAS PENDIDIKAN DI INDONESIA.

Johni Dimyati, M. M. (2013). Metodologi Penelitian Pendidikan dan Palikasinya Pada Pendidikan Anak Usia Dini (PAUD). Kencana.

Lu, Y. (2012). Education of children left behind in rural China. Journal of Marriage and Family, 74(2), 328-341.

Mansir, F. (2017). Model Pendidikan Karakter Di Perguruan Tinggi Islam (Studi Pada Umi Dan Uin Alauddin Makassar).

Mansir, F. (2018). Pendekatan Psikologi Dalam Kajian Pendidikan Islam. Psikis: Jurnal Psikologi Islami, 4(1), 61-73.

Mansir, F. (2019). Implications of Teacher Certification on Professionalism and Welfare of 21th Century PAI Teachers. Tadrib, 5(2), 138-152.

Mansir, F. (2020). Diskursus Sains dalam Kurikulum Pendidikan Agama Islam di Sekolah dan Madrasah Era Digital. Kamaya: Jurnal Ilmu Agama, 3(2), 144-157.

Mansir, F. (2020). Identitas Guru PAI Abad 21 Yang Ideal pada Pembelajaran Fiqh di Sekolah dan Madrasah. Muslim Heritage, 5(2), 435.

Mansir, F. (2020). Kesejahteraan Dan Kualitas Guru Sebagai Ujung Tombak Pendidikan Nasional Era Digital. Jurnal IKA PGSD (Ikatan Alumni PGSD) UNARS, 8(2), 293303.

Mansir, F. (2020). Manajemen Pondok Pesantren di Indonesia dalam Perspektif Pendidikan Islam Era Modern. QALAMUNA: Jurnal Pendidikan, Sosial, Dan Agama, 12(2), 207216.

Mansir, F. (2020). The impact of globalization on islamic education toward fiqh learning existence in covid-19 pandemic period. ATTARBIYAH: Journal of Islamic Culture and Education, 5(2), 123-133.

Mansir, F. (2020). The Leadership of Personnel Management in Islamic Education: Emerging Insights from an Indonesian University. Edukasia Islamika, 1-16.

Mansir, F. (2020). The Urgency of Fiqh Siyasah In Islamic Education Learning At Madrasas And Schools. POTENSIA: Jurnal Kependidikan Islam, 6(2), 142-154.

Mansir, F. (2021). Aktualisasi Pendidikan Agama dan Sains dalam Character Building Peserta Didik di Sekolah dan Madrasah. J-PAI: Jurnal Pendidikan Agama Islam, 7(2).

Mansir, F. (2021). Analisis model-model pembelajaran fikih yang aktual dalam merespons isu sosial di sekolah dan madrasah. Ta'dibuna: Jurnal Pendidikan Islam, 10(1), 8899.

Mansir, F. (2021). Paradigma Pendidikan Inklusi Dalam Perspektif Pendidikan Islam: Dinamika Pada Sekolah Islam. Tadrib, 7(1), 1-17.

Mansir, F. (2021). The Urgency of Fiqh Education and Family Role in The Middle of Covid19 Pandemic For Students In School and Madrasah. Kamaya: Jurnal Ilmu Agama, 4(1), 1-10.

Marliani, R. (2019). Psikologi Perkembangan Anak \& Remaja. 
Sari, S., \& Bermuli, J. (2021). Pembentukan Karakter Tanggung Jawab Siswa pada Pembelajaran Daring Melalui Implementasi Pendidikan Karakter. Jurnal Kependidikan: Jurnal Hasil Penelitian dan Kajian Kepustakaan di Bidang Pendidikan, Pengajaran dan Pembelajaran, 7(1), 110-121. doi:https://doi.org/10.33394/jk.v7i1.3150

Sewell, K., \& Newman, S. (2014). What is education. Education Studies: An Issue Based Approach.

SUKRI, S. (2015). PENANGGULANGAN KEBODOHAN DALAM AL-QUR 'AN (Kajian Tematik). Institut Agama Islam Negeri Palopo.

Suntana, I. (2015). Etika Pendidikan Anak.

Tanu, I. K. (2019). Pentingnya Pendidikan Anak Usia Dini Agar Dapat Tumbuh dan Berkembang sebagai Generasi Bangsa Harapan di Masa Depan. Adi Widya: Jurnal Pendidikan Dasar, 2(2), 19-29.

Taubah, M. (2015). Pendidikan Anak dalam Keluarga Perspektif Islam. Jurnal Pendidikan Agama Islam (Journal of Islamic Education Studies), 3(1), 109-136.

Veronika, R., \& Andriani, D. (2021). Pengembangan Model Pembelajaran Pendidikan Karakter Berbasis Kearifan Lokal pada Mahasiswa Program Studi Perhotelan Politeknik Bosowa. Jurnal Kependidikan: Jurnal Hasil Penelitian dan Kajian Kepustakaan di Bidang Pendidikan, Pengajaran dan Pembelajaran, 7(1), 205-213. doi:https://doi.org/10.33394/jk.v7i1.3186

Yus, A. (2011). Model pendidikan anak usia dini. Kencana.

Yuliani, Y. (2016). Pendidikan di Indonesia dalam Human Development Index (Hdi). Jurnal Rontal Keilmuan Pancasila dan Kewarganegaraan, 2(2). 